УДК 616.314-008.4.-257.01

\title{
МОДЕРНІЗАЦІЯ ВИЩОЇ УКРАЇНСЬКОЇ ОСВІТИ ШЛЯХОМ ВПРОВАДЖЕННЯ ПОЛОЖЕНЬ БОЛОНСЬКОГО ПРОЦЕСУ. ОГЛЯД ЛІТЕРАТУРИ
}

\author{
О. М. Виноградова, Р. М. Гнідь, Т. І. Пупін \\ Львівський національний медичний університет імені Данила Галиџького

\section{MODERNIZATION OF THE HIGHER UKRAINIAN EDUCATION THROUGH THE INTRODUCTION OF PROVISIONS OF THE BOLOGNA PROCESS. LITERATURE REVIEW}

\author{
O. N. Vynogradova, R. M. Gnid, T. I. Pupin \\ Lviv National Medical University by Danylo Halytsky
}

\begin{abstract}
У статті представлено огляд літератури щодо реформування української вищої школи шляхом модернізації її за європейським прикладом. Великою підтримкою у цьому став Болонський процес, завдання якого - приведення вищої освіти в європейських країнах до єдиних стандартів та критеріїв.
\end{abstract}

In the article the review of literature is presented in relation to the reformation of Ukrainian higher school through its modernization on the European example. The Bologna process a task of that is a bringing of higher education in the European countries to the single standards and criteria became the large support herein.

Вступ. Спроби вдосконалення європейської освіти за єдиними стандартами почалися з 1957 року, коли була підписана Римська угода. У ній ставилися принципово нові завдання: приведення національних законодавств у сфері освіти до загальноєвропейських норм, розширення доступу до вищої освіти, підвищення академічної мобільності студентів і їх затребуваності на ринку праці, створення довгострокових систем навчання. Згодом ці ідеї були розвинені в рішеннях конференцій міністрів освіти європейських країн (1971, 1976), у Маастрихтському договорі (1992). Надалі під егідою ЄС, Ради Європи впроваджувалися різноманітні програми $[2,5]$.

У 1997 році Рада Свропи і ЮНЕСКО розробили та прийняли Лісабонську конвенцію про кваліфікації, що відносяться до вищої освіти в країнах Свропи. Цю конвенцію підписали 43 країни, у тому числі і Україна. Лісабонська угода не переслідувала уніфікації вищої освіти, а визнавала та поважала цінність різноманітних освітніх систем, разом з тим підкреслюючи, що створення умов, при яких більшість людей, скориставшись досягненнями національних систем

(c) О. М. Виноградова, Р. М. Гнідь, Т. І. Пупін освіти й науки, зможуть бути затребуваними на європейському ринку праці. Громадянам європейських країн повинні бути доступні загальні цінності освіти, науки та культури всіх країн.

У 1999 році 29 країн Європи в місті Болонья офіційно задекларували і почали процес об'єднання чотирьох тисяч європейських вищих навчальних закладів, де вчаться більш ніж 12 мільйонів студентів, у єдиний освітній простір [3].

Основна частина. Вища освіта в Україні, на жаль, стаючи неліквідною і неконкурентоспроможною, поступалася рівню освіти розвинених країн і не визнавалася європейським співтовариством. Така несприятлива ситуація вимагала продуманих і системних реформ, щоб дати можливість реалізуватися величезному інтелектуальному потенціалу, який $\epsilon$ в нашому суспільстві. Найбільш прийнятним способом реформування української вищої школи є модернізація його за європейським прикладом, великою підтримкою в цьому плані повинен стати Болонський процес, завдання якого - приведення вищої освіти в європейських країнах до єдиних стандартів і критеріїв [1].

Коли в суверенній Україні з'явилася можливість створити систему підготовки лікарів такою, якою 
вона була в розвинених і багатих країнах світу, то була дуже швидко розроблена й прийнята програма реформування вищої медичної освіти на 1992-2002 pp.

Тоді відразу вдалося перейти на переддипломну підготовку лікарів із трьох факультетів (лікувальний, педіатричний, медико-профілактичний), була введена модульно-рейтингова система навчання та оцінок знань студентів.

Сьогодні в Україні робиться все можливе для впровадження принципів Болонського процесу. Так, питання реформування вищої освіти України відображені в наказі Президента України від 14 вересня 2000 року "Про Програму інтеграції України в Свропейський Союз", у відповідних розпорядженнях Кабінету Міністрів, у постановах Міністерства освіти і науки України. Національна доктрина розвитку освіти пройшла експертизу Ради Свропи. В Україну приїжджали експерти, які знайомилися із практикою впровадження задекларованих вітчизняним законодавством норм у наших університетах і коледжах. 31993 по 2003 рік вищі навчальні заклади України разом із провідними університетами Свропи виконали 105 проектів TEMPUS/TACIS, що дало можливість запровадити загальні навчальні програми, нові принципи керування вузами, підготувати та видати сучасні підручники, напрацювати підходи до взаємного визнання документів про освіту. В 2006/2007 навчальному році у всіх вузах України III-IV рівнів акредитації впроваджена кредитно-трансферна система ECTS. Підготовлений відповідний пакет інноваційних нормативних документів ECTS, розроблені рекомендаціїта здійснюються організаційні заходи щодо впровадження додатка до диплома європейського зразка (Diploma Supplement). Виконання цього пункту є обов'язковою умовою для всіх країн-учасниць Болонського процесу [7].

Запровадження ECTS - Свропейської системи перезаліку кредитів - $€$ однією з найбільше технічно й змістовно складних завдань у рамках Болонського процесу. Цей інструмент, що забезпечує прозорість, порівнянність об'єму вивченого матеріалу та, відповідно, можливість академічного визнання кваліфікацій і компетенцій, виник спочатку в рамках європейської програми Еразмус в 1988 році і на сьогодні включає більш ніж 1100 університетів і мережу “ліній сприяння" (ECTS Helplines). Порівнянність навчальних планів дозволяє студентам вибирати програми, відповідні одержуваним ними кваліфікаціям, які, за умови їх успішного завершення, зараховуються як пройдений матеріал у своєму університеті. Кредити відображають обсяг роботи, що вимагається для завершення кожного курсу, стосовно загального обсягу роботи, необхідної для програми повного академічного року в університеті, включаючи лекції, семінари, практичні заняття, самостійну роботу, іспити та тести. Кредитами називаються умовні одиниці, у яких визначається об'єм освіти. За кожною такою одиницею стоїть певна кількість освоєних понять, зв'язків між поняттями, напрацьовані навички, тобто загальна трудомісткість отриманих знань і вмінь, включаючи самостійну роботу студентів і складання ними проміжних і підсумкових іспитів, інші види навчальної роботи. Співвідношення кількості аудиторних годин і годин самостійної роботи централізовано не регламентується, хоча в деяких країнах навчальне навантаження повинно включати 50 \% і більше самостійної роботи студента.

У залікових одиницях обчислюється об'єм усіх видів навчальної роботи: одна залікова одиниця становить 36 академічних годин.

Академічний кредит - одиниця трудомісткості навчальної праці студента. За семестр нараховується рівно 30 академічних кредитів. За навчальний рік нараховується рівно 60 академічних кредитів. Для одержання європейського диплома бакалавра потрібно набрати 180 годин-кредитів (три роки навчання) або не менш 240 годин-кредитів (чотири роки навчання). Для одержання ступеня магістра студент повинен, як правило, набрати в цілому не менше ніж 300 кредитів (п'ять років навчання). Кількість кредитів за дисципліну не може бути дробовим (як виняток, допускається нараховування 0,5 кредиту), тому що додавання кредитів за семестр повинно давати число 30.

Кредити нараховуються після успішного складення (позитивна оцінка) підсумкового іспиту з дисципліни (іспиту, заліку, тесту тощо). Кількість кредитів, що нараховуються з дисципліни, не залежить від оцінки. Відвідуваність студентом аудиторних занять враховується за розсудом вузу, але не гарантує нарахування кредитів [7-9].

Кредитна система, яка акумулюється, дає можливість врахувати всі досягнення студента, не тільки навчальне навантаження, але і участь його в наукових дослідженнях, конференціях, предметних олімпіадах тощо. Завдяки накопичувальній системі кредитів, студент зможе вступити до університету однієї країни, а закінчити його в іншій; перемінити в процесі навчання університет або вибрану спеціальність; закінчити навчання на будь-якому етапі, отримавши ступінь бакалавра або магістра, продовжити освіту у зручний для себе період життя. 
Забезпечення академічної мобільності студентів і викладачів як один із компонентів Болонського процесу передбачає таке:

1. Студент повинен провчитися в закордонному ВНЗ семестр або навчальний рік.

2. Він навчається мовою країни перебування або англійською мовою; цими самими мовами складає поточні й підсумкові іспити.

3. Навчання за кордоном за програмами мобільності для студента безкоштовне - ВНЗ, що приймає, грошей за навчання не бере.

4. Студент оплачує сам: дорогу, проживання, харчування, медичні послуги та навчальні заняття поза погодженою (стандартною) програмою.

5. У базовому ВНЗ (до якого студент вступав) студенту зараховуються отримані кредити, якщо стажування погоджене з деканатом; він не перездає ніякі дисципліни за період навчання за кордоном.

6. ВНЗ має право не зараховувати в рахунок своєї програми академічні кредити, які студент отримав в інших ВНЗ без узгодження з деканатом.

Заохочується одержання студентом спільних і подвійних дипломів.

Основна вимога Болонської декларації-підвищення якості освіти. Для вищої медичної школи України це, насамперед, забезпечення прийнятного рівня клінічної підготовки студентів.

Прийшов час, навчивши студента базисних знань у своїй дисципліні, навчити його вирішувати поставлені спочатку типові, а потім і нетипові ситуаційні завдання, поступово підводячи до творчості. Звідси і поява нових понять про ступені знань. Відповідати першому ступеню - це мати уявлення про що-небудь, другим ступенем є саме знання, далі іде вміння демонстрації професійних навичок. На 4-6 курсах студент повинен вміти застосувати отримані раніше знання щодо конкретного хворого. Викладачі медичних вузів постійно стикаються з наявністю певних проблем, які впливають на якість підготовки майбутніх лікарів. До них слід віднести слабкий вихідний рівень знань у деяких студентів, недостатні мотивації до набуття навичок самостійної роботи з пацієнтами, а також високе навантаження на викладачів. В об'єднаній Європі співвідношення викладач/студенти 1:4 або 1:5, залежно від країни, а в нас-1:9-1:11, та й ще величезне аудиторне навантаження на професорів, доцентів і асистентів. Тільки в Україні викладачам платять за кількість відпрацьованих годин, а не за кількість студентів, яких вони навчають. У США й на Заході існують університетські клініки3 потужними лабораторіями, професорами, які не тільки читають лекції, але й провадять дослідження, займаються науковими дослідженнями 3 молодими колегами - студентами, ординаторами, аспірантами не заради статей, дисертацій, монографій або звань, а заради одержання реального результату, який можна продати [5-7].

Невирішеною проблемою в багатьох вузах України на сьогодні залишається забезпечення клінічними базами, оснащеними сучасним обладнанням для діагностичної та лікувальної роботи. Високі рейтинги, як правило, мають ті медичні вузи, у яких є власні клінічні бази, оскільки вони є основою для якісної підготовки лікарів. Але, на жаль, у цей же час, клініки для медичних вузів не тільки не будуються, але й почався процес витиснення вузів з муніципальних лікарень (3'являються платні палати, комерційні пацієнти).

Звідси основною проблемою вітчизняного освітнього процесу є недостатній рівень практичної підготовки випускників вузів. У процесі навчання практично не вчать алгоритму дій у нестандартних ситуаціях. У результаті цього 10-20 \% випускників при роботі із хворими допускають в основному такі лікарські помилки, як: погано зібраний анамнез, недоліки в клінічному обстеженні (огляд, пальпація, аускультація), лікувально-профілактичних заходах і лабораторно-інструментальному обстеженні.

У зв'язку із цим, в теперішній час, на старших курсах є важливим впровадження більш досконалого нетрадиційного методу викладання внутрішніх хвороб, який у світовій педагогічній практиці має назву “безперервний пізнавальний цикл” [10].

При постановці діагностичних і терапевтичних завдань викладач мотивує студентів у пізнанні діагностичних і терапевтичних прийомів (на основі вибору ними діагностичного методу й схеми лікування), які їм до цього часу невідомі у застосовуванні. Після цього викладач допомагає студентам знайти закономірності (логіку обстежень і лікування хворого) в отриманій ними ціннісній інформації, формулює попередній діагноз і пропонує схему лікування так, як би це зробив досвідчений лікар, виходячи з патогенетичних механізмів, які полягають в основі хвороби в їхньому індивідуальному виразі. Цей підхід важливий при розв' язанні студентами клінічних ситуаційних завдань із використанням імовірнісного підходу й обгрунтуванням правильної відповіді. Одночасно допускається користування джерелами літератури, виходячи із принципу “від хворого до книги”, для того, щоб зв’язати отримані нові знання з наступними обстеженнями нових хворих і розв' язанням проблемних діагностичних і терапевтичних ситуацій, з якими 
студент може зустрітися в майбутній реальній лікарській діяльності.

При цьому дуже важливий багаторівневий процес контролю навчання: початковий поточний контроль, навчання на репродуктивному рівні навчання, контроль на продуктивному рівні з одержанням нових знань на основі тих, які є обгрунтованими, i, нарешті, поточна атестація та підсумковий контроль рівня i якості навчання протягом певного періоду навчального часу (семестру). Поточний контроль $\epsilon$ головним етапом у навчанні $з$ необхідністю досягнення запланованого рівня і якості навчання, а атестація (іспит) - етап, що констатує досягнутий рівень і якість навчання з оцінками “"задовільно”, “добре”, “відмінно” з відповідною бальною оцінкою в рамках кредитномодульної системи.

Для студента $€$ важливим не тільки осмислення та освоєння інформації, а також оволодіння прийомами i практичним впровадженням з використанням матеріалу, що вивчається, прийняттям певних конструктивних рішень. Розширюється також повноцінна самостійна робота над змістом модульного матеріалу

\section{Списоклітератури}

1. Алексєєв В. О. Методика проведення лекційних занять у вищій школі / В. О. Алексєєв // Педагогіка формування творчої особистості у вищій і загальноосвітній школі. -2009. - Вип. 3. - С. 8-12.

2. Болонський процес у фактах і документах / [М. Ф. Степко, Я. Я. Болюбаш, В. Д. Шинкарук та ін.]. Київ ; Тернопіль : Економічна думка, 2003. - 52 с.

3. Ван дер Венде М. К. Болонская декларация: расширение доступности и повышение конкурентоспособности высшего образования в Европе / М. К. Ван дер Венде // Высшее образование в Европе. - 2003. - T. XXV, № 3.C. 22-24.

4. Вербицкий А. А. Активное обучение в высшей школе: контекстный подход / А. А. Вербицкий. - М. : Высшая школа, 1991. -207 c.

5. Довженко О. В. Сорбоннская и Болонская декларации: информация к размышлению / О. В. Довженко // Beстник высшей школы:Alma mater. -2000. - № 6. тої або іншої навчальної теми. При цьому викладач закріплюється за невеликою групою студентів, пізнавальною діяльністю яких він керує, враховуючи їхні індивідуальні інтереси, інтелектуальні здібності, плани на освоєння навчального матеріалу та плани на майбутнє. У цьому полягає суть так званого особистісно-орієнтованого підходу у навчанні.

Висновки. На підставі набутого досвіду і практики стає очевидним, що впровадження кредитно-модульної системи організації навчального процесу є важливим чинником стимулювання ефективної роботи викладача та студента з урахуванням часу безпосереднього їхнього спілкування в процесі навчання. При цьому найефективніший метод активізації навчального процесу - це комбінація навчальної, наукової та практичної діяльності. Із цією метою $є$ важливим входження в систему безперервної освіти.

Перспективою подальших досліджень може стати проведення подальших пошуків розробки оптимальних угод при співробітництві між вищими навчальними закладами Європейського простору освіти.

6. Згуровський М. 3. Болонський процес: головні принципи та шляхи структурного реформування вищої освіти України / М. З. Згуровський. -К. : Політехніка, 2006.-200 с.

7. Навчальний процес у вищій педагогічній школі : навч. посіб. / за ред. О. Г. Мороза. - К. : НПУ ім. М. П. Драгоманова, 2001. -337 с.

8. Основні засади розвитку вищої освіти України в контексті Болонського процесу (документи і матеріали 20032004 років) / за ред. В. Г. Кременя. -К., 2003. - 147 с.

9. Павленко О. В. Сучасні підходи до покращення післядипломної освіти лікарів-стоматологів / О. В. Павленко, Т. М. Волосовець // Медична освіта. -2002.-№ 1. - С. 17-20.

10. Система управління якістю медичної освіти в Україні / [Ю. В. Вороненко, І. Є. Булах, Є. Г. Гончарук та ін.]. - Дніпропетровськ : Арт-Прес, 2003. -211 с.

Отримано 26.01.15 